\title{
PREPARATION AND CHARACTERIZATION OF BONDED-PHASES OF CALIXARENE-SULFONYL- CARBOXAMIDES IN PARTIAL-CONE CONFORMATION FOR DETERMINATION OF SALBUTAMOL IN LIVESTOCK BY NANO-MEDIATED BONDED-PHASES: NANO-BASKETS OF CALIXARENE IN PARTIAL-CONE CONFORMATION
}

\author{
BAHRAM MOKHTARI, KOBRA POURABDOLLAH* \\ Department of Chemical Engineering, Shahreza Branch, Islamic Azad University, Shahreza, Iran. \\ (Received: September 29, 2011 - Accepted: March 1, 2012)
}

\begin{abstract}
A new sensitive method for determination of salbutamol, as a nutrient repartitioning agent, in livestock is presented to protect the consumers. Eight nanobaskets of $p$-tert-calix[4]arene bearing di-[N-(X)sulfonyl carboxamide] and di-(1-propoxy) in partial-cone conformation were synthesized and were used to prepare bended phases of HPLC-UV. The new synthesized bonded-phases were characterized and optimized, the bonding interactions of solute and stationary phases were examined and the main interactions were reported. The results revealed that for the best bonded-phase, the LOD and LOQ were 0.02 and $0.06 \mu \mathrm{g} /$ $\mathrm{mL}$, respectively.
\end{abstract}

Keywords: Bonded-Phase; Partial-Cone Conformation; Calixarene; Salbutamol; nanobasket.

\section{INTRODUCTION}

Salbutamol (albuterol) is the international nonproprietary (United States) adopted name for 4-(2-(tert-butylamino)-1-hydroxyethyl)-2-(hydroxymethyl) phenol (Figure 1), which is used for the treatment of asthma in both humans and animals, is a synthetic $\beta_{2}$-agonist. In high doses, salbutamol exhibits a metabolic effect, which results in an increase in muscle mass and a decrease in adipose tissue. So, the compound is also misused as nutrient repartitioning agent in livestock by diverting nutrients from fat deposition in animals to the production of muscle tissues [1]. This misuse had caused some severe accidental poisonings in humans $[2,3]$. Therefore, all $\beta_{2}$-agonists are banned for growth promotion in animal production. In order to protect consumers, specific and sensitive methods for the identification and quantitation of salbutamol in meat and other food are required.<smiles>CC(C)(C)NCC(O)c1ccc(O)c(CO)c1</smiles>

Figure 1. The chemical structure of salbutamol.

Nano-baskets of calixarenes and calixcrowns are a versatile class of macrocycles, which have been subject to extensive research in development of many extractants, (using gas chromatograph, Teif Gostar Faraz Co.) transporters and stationary phases over the past four decades [4-6]. Functionalization of calix[4]arenes at both the upper rim and the lower rim has been extensively studied [7-9]. Attaching donor atoms to the lower rim of a calix[4]arene can improve the binding strength of the parent calixarene dramatically [10-12]. Calixarene-bonded stationary phases are preferable to the use as mobile-phase additives, because the UV detection of analytes is prevented by strong absorbance of calixarenes [13-15]. Additionally, poor solubility of most calixarenes precludes their applications as additives in aqueous eluents. With the advent of various functionaliziation methods of calixarenes, more applications have been reported for calixarene bondedphases. The resulting interactions of different calixarenes stationary phase influence the retention factors and improve the selectivity of the solutes. The modification of the calixarenes, for instance, by varying the conformations, ring size, and substitutents, enable a more enhanced interaction spectrum and can improve the specificity for guest molecules [16-21]. Table 1 summarizes the recent research carried out using calixarenes in liquid chromatography other applications of calixarenes are reported in microextraction [44], desalination [45] and drug developments [46].

In the present work, the synthesis of eight derivatives of $p$-tert-calix[4] arene bearing di-[N-(X)sulfonyl carboxamide] and di-(1-propoxy) in partialcone conformation and the preparation of its bonded silica stationary phase were described $\left[\mathbf{X}=\right.$ Phenyl $(\mathbf{0 1 , 0 5}), p-\mathrm{CH}_{3}$ Phenyl $(\mathbf{0 2 , 0 6}), p$-OHPhenyl $(\mathbf{0 3 , 0 7}), p$-NO Phenyl $(\mathbf{0 4 , 0 8})]$. A new method for determination of salbutamol in the livestock meat samples was set up by using the new calix[4]arene-based column. The chromatographic performance using salbutamol as well as the influence of methanol content (in mobile phase) on the chromatographic behavior of the solutes was investigated. Figure 2 shows the expanded chemical structure of derivatives 01-08.
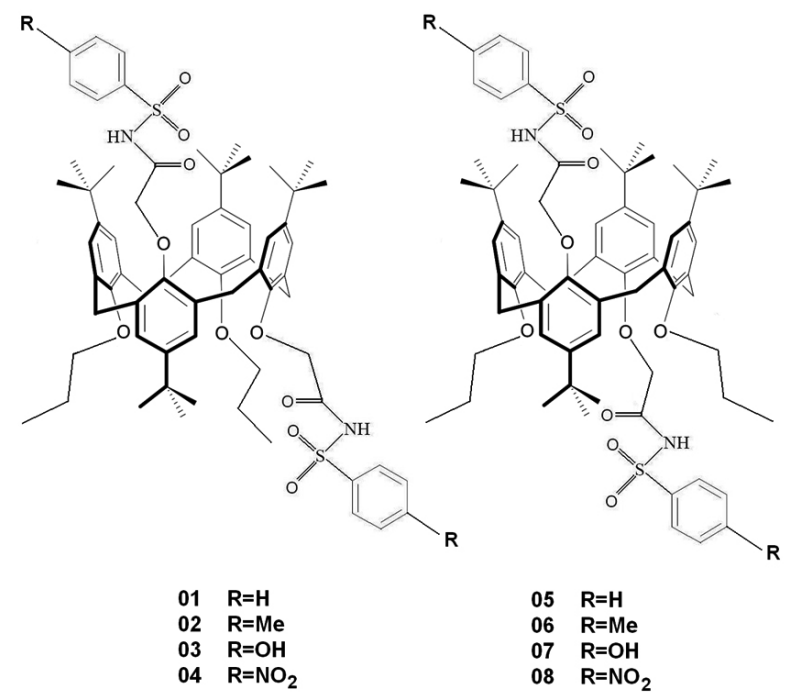

Figure 2. Chemical structure of derivatives 01-08.

\section{Experimental Procedure}

\subsection{Materials and Apparatus}

All solvents and analytes used were of analytical grade and obtained from Merck Chemical Company unless specially mentioned. Silica gel (with particle size of $5 \mu \mathrm{m}$, pore size of $100 \AA$ and specific surface area of $300 \mathrm{~m}^{2} / \mathrm{g}$ ), HPLCgrade methanol $(\mathrm{MeOH})$ and $\gamma$-glycidoxypropyltrimethoxysilane (KH-560) were used. A phosphate buffer $(0.5 \%, \mathrm{w} / \mathrm{w}, \mathrm{pH} 4.5)$ was prepared by mixing $\mathrm{KH}_{2} \mathrm{PO}_{4}$ with ultra-high quality pure water, and filtered through a $0.45 \mu \mathrm{m}$ filter before use. Water was purified by using Milli-Q purification equipment.

The stock solution of Salbutamol $(250 \mathrm{mg} / \mathrm{mL})$ was prepared by dissolving the reference substance in $\mathrm{MeOH}$, and stored in the refrigerator. The standard working solutions were prepared by diluting aliquots of the stock solution to obtain concentrations ranging from 0.1 to $2.0 \mu \mathrm{g} / \mathrm{mL}$. The calibration graph was constructed by plotting the peak areas obtained at wavelength $243 \mathrm{~nm}$ versus the corresponding injected concentrations. The samples were treated according to the following method: tissue samples $(2.000 \mathrm{~g})$ was transferred to a polypropylene centrifuge tube $(50 \mathrm{~mL})$ with stopper, ammonium acetate $(10$ 
$\mathrm{mL}, 20 \mathrm{mmol} / \mathrm{L}$ ) buffer solution was added to the tube, then $\beta$-glucuronidase-aryl sulfatase $(50 \mu \mathrm{L}$, containing $134600 \mathrm{U} / \mathrm{mL} \beta$-glucuronidase and $5200 \mathrm{U} / \mathrm{mL}$ aryl sulfatase) was added; after that, oscillated on the vortex oscillator $(2 \mathrm{~min}$ ) and sonicated ( $20 \mathrm{~min}$ ) by using a ultrasonic processor, then put into a incubator (16 $\mathrm{h}$, $\left.37^{\circ} \mathrm{C}\right)$. After the tube was centrifuged at $4000 \mathrm{r} / \mathrm{min}(10 \mathrm{~min})$, the supernate was transferred into another tube. Then, chloroform $(5.0 \mathrm{ml})$ was added, oscillated and sonicated again. The supernate was applied to Waters Oasis MCX cartridge, which was activated with methanol ( $5 \mathrm{~mL})$, water $(5 \mathrm{~mL})$, and followed by hydrochloric acid $(5 \mathrm{~mL}, 0.01 \mathrm{~mol} / \mathrm{L})$ solution. The cartridge was washed with ethyl acetate/ammonium hydroxide $(6 \mathrm{~mL}, 97: 3$, v/v), the eluent was collected into a glass tube, and evaporated until dryness under a stream of nitrogen at $40^{\circ} \mathrm{C}$ water bath, the residue was reconstituted in $0.2 \%$ formic acid in water/acetonitrile $(1.0 \mathrm{~mL}, 90: 10$, $\mathrm{v} / \mathrm{v})$. The resulting solution was filtered through $0.22 \mu \mathrm{m}$ filter and the filtrate $(10 \mu \mathrm{L})$ was ready for analysis.

Table 1. The list of calixarenes used as stationary phases.

\begin{tabular}{|c|c|c|}
\hline Type of calixarene & Analytes were used & References \\
\hline calix $[4,6,8]$ arene & PAHs & {$[22]$} \\
\hline $\begin{array}{l}\text { calixBzCl, calixBzF } F_{5} \text {, calixBzNO }{ }_{2} \text {, calixBn, calixBph, } \\
\text { calixBnOMe }\end{array}$ & $\begin{array}{l}\text { pentylbenzene, butylbenzene, triphenylene, o-terphenyl, } \\
\text { caffeine, phenol, benzylamine }\end{array}$ & {$[23]$} \\
\hline $\begin{array}{l}\text { caltrex AI-calix[4]aren, caltrex AII-calix[6]aren, caltrex AIII- } \\
\text { calix[8]aren, caltrex BI-p-tert-butyl-calix[4]aren, caltrex BII- } \\
\text { p-tert-butyl-calix[6]aren, caltrex BIII- } \text {-tert-butyl-calix[8] } \\
\text { aren, caltrex Science-calix[4]aren, } p \text {-tert-butyl-calix[4] aren } \\
\text { and resorcinarene-bonded phase (caltrex resorcinaren) }\end{array}$ & $\begin{array}{l}\text { benzene, toluene, ethylbenzene, naphthalene, } \\
\text { propylbenzene, anthracene, phenanthrene, bipheny, } \\
o \text {-terpheny, triphenylene, promazine, propranolol, } \\
\text { chlorpromazine, promethazine, amitriptyline, } \\
\text { nortriptyline, o-cresol, phenol, dimethylacetamide, } \\
\text { benzoic acid, naproxen, diclofenac, benzoic acid, } \\
\text { salicylic acid, procaine and ephedrine }\end{array}$ & {$[24]$} \\
\hline p-tert-butyl-calix[8]arene & steroids & {$[25]$} \\
\hline calix[6]arene- $p$-sulfonate & $\begin{array}{l}\text { nitrophenol, methoxyphenol, cresol, aminophenol and } \\
\text { chlorophenol }\end{array}$ & {$[26]$} \\
\hline C-tetraundecylcalix[4]resorcinarene & cytosine, uracil and thymine & {$[27]$} \\
\hline calix[8]arene & tricyclic neuroleptic & {$[28]$} \\
\hline calix[4]arenes & benzene or uracil derivatives & {$[29]$} \\
\hline caltrex BIIE & paracetamol, caffeine and acetylsalicylic acid & {$[30]$} \\
\hline caltrex AIII & celecoxib & {$[31]$} \\
\hline fluorinated calix[4]arene & fluorine compounds & {$[32]$} \\
\hline p-tert-butyl-calix[8]arene & aromatic carboxylic acids & {$[33]$} \\
\hline $\begin{array}{l}\text { 9-amino(9-deoxy)-epiquinine calix[4]arene, } \\
\text { 9-amino(9-deoxy)-quinine calix[4]arene }\end{array}$ & cyclic amino acids & {$[34]$} \\
\hline $\begin{array}{l}\text { caltrex AI, caltrex AII, caltrex AIII, caltrex BI, caltrex BII } \\
\text { and caltrex BIII }\end{array}$ & $\begin{array}{l}\text { PAHs, phenols, substituted aromatics, xanthines, } \\
\text { barbituric acid, benzoic acid esters }\end{array}$ & {$[35]$} \\
\hline calix[4]arene tetradiethylamide & amino acid ester hydrochlorides & {$[36,37]$} \\
\hline calix[4]resorcinarene and calix[4,6,8]arene & flupentixol, chlorprothixene, clopenthixol, and doxepin & [38] \\
\hline p-tert-butylcalix $[4,6,8]$ arene & $\begin{array}{l}\text { disubstituted aromatics, uracil derivatives, and estradiol } \\
\text { epimers }\end{array}$ & [39] \\
\hline$p$-tert-butylcalix $[4,6,8]$ arene & peptide bond isomers of proline & {$[40]$} \\
\hline p-tert-butyl-calix[4]arene & nucleosides, PAHs and bases & [41] \\
\hline calix[6]arene & nucleosides and PAHs & {$[42]$} \\
\hline$p$-tert-butyl-calix[4]arene & $\begin{array}{l}\text { basic aromatic compounds, polar and non-polar } \\
\text { aromatic compounds, and PAHs }\end{array}$ & {$[43]$} \\
\hline
\end{tabular}

Chromatographic analyses were carried out by using an Agilent 1200 series system equipped with a 1200 model quaternary pump, a G1314A model Multiple Wavelength UV-vis detector, a G1316A model thermostated column compartment, a 1322A model vacuum degasser, and an Agilent Chemstation B.03.02 Patch data processor. The homemade calixarene column was filled using a packing machine under the pressure of $50 \mathrm{MPa}$. An Eclipse XDB- $\mathrm{C}_{18}$ column (Agilent, $150 \mathrm{~mm} \times 4.6 \mathrm{~mm}$ i.d., $5 \mu \mathrm{m}$ ) was used as a comparison with the homemade calixarene column.

\subsection{Preparation of Stationary Phases}

Figure 3 shows the preparation process of a new calix[4]arene-bonded silica gel stationary phase $\mathbf{0 1}$. Active silica gel $(5.0 \mathrm{~g})$ was suspended in dry toluene $(50 \mathrm{~mL}$, freshly distilled), and then $\mathrm{KH}-560(6.0 \mathrm{~mL})$ and triethylamine $(1.0 \mathrm{~mL}$, used as a catalyst) was added to this suspension. The mixture was stirred and heated to $80^{\circ} \mathrm{C}$ under the protection of nitrogen atmosphere $(8 \mathrm{~h})$ After the reaction finished, the solid was filtered by $1.5 \mu \mathrm{m}$ filter, and washed in sequence with toluene and acetone, then dried at $80^{\circ} \mathrm{C}$ under vacuum $(8 \mathrm{~h})$. Finally, $\gamma$-glycidoxypropyl bonded silica gel $(\gamma$-GBSG) was obtained and used as a precursor in the following reaction. 


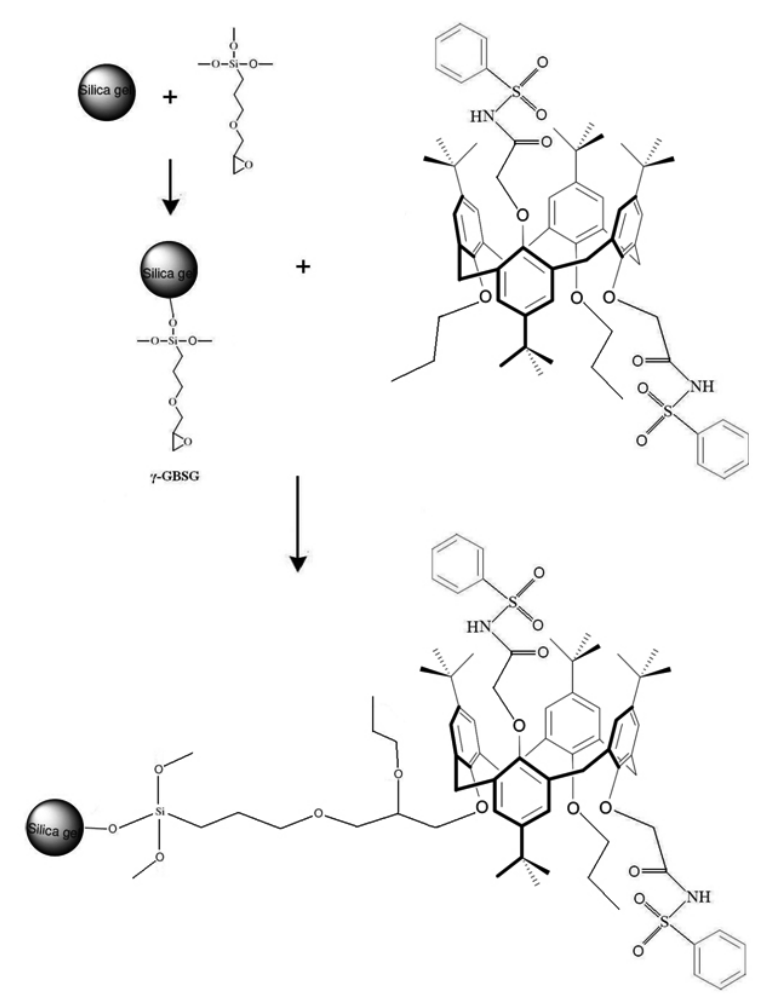
01.

Figure 3. Preparation of a calix[4]arene-bonded silica gel stationary phase

Each of the para-tert-butyl calix[4]arenes 01-08 (3.0 g, $3.1 \mathrm{mmol}), \mathrm{NaH}$ $(0.6 \mathrm{~g})$, and toluene $\left(60 \mathrm{~mL}\right.$, freshly distilled) were stirred at $80^{\circ} \mathrm{C}$ for $30 \mathrm{~min}$, then the supernatant liquid was transferred to a $100 \mathrm{~mL}$ three-neck flask, $\gamma$-GBSG ( $3.0 \mathrm{~g}$ ) was added, and the mixture was refluxed with the catalyst for $48 \mathrm{~h}$. The whole process was carried out under nitrogen atmosphere. After the reaction finished, the product was filtered and washed in sequence with toluene, acetone, methanol and distilled water. Subsequently, stationary phases were obtained and dried at $100^{\circ} \mathrm{C}$ under vacuum for $8 \mathrm{~h}$, then cooled to room temperature in a desiccator.

\subsection{Characterization of Stationary Phases}

The characterization of the developed stationary phases was carried out by elemental analysis, IR and thermal gravimetric analysis. Thermal gravimetric analysis (TGA) was carried out with a Shimadzu DT-40 thermal analyzer, the analysis was performed from $40^{\circ} \mathrm{C}$ to $650^{\circ} \mathrm{C}$ at heating rate of $10^{\circ} \mathrm{C} / \mathrm{min}$ in argon atmosphere with a gas flow rate of $20 \mathrm{~mL} / \mathrm{min}$.

Table 2 shows the elemental analysis results of $\gamma$-GBSG and stationary phases. The result indicates stationary phases own higher content of carbon, nitrogen and sulfur than that of $\gamma$-GBSG, which confirmed that the calixarene was successfully immobilized onto the silica gel. The bonded amount of calix[4]arene derivatives onto the silica gel was calculated by subtracting that of $\gamma$-GBSG. According to the carbon content of the bonded silica gel stationary phases, the resulting stationary phases contain about $10 \%$ carbon corresponding $0.05 \mathrm{mmol}$ calix[4]arene per gram of silica-gel.

Moreover, the bonded stationary phases were characterized by infrared spectroscopy. From IR spectra, the characteristic absorption band of the benzene ring appears around 1625,1552 and $1486 \mathrm{~cm}^{-1}$, peaks around 2960 and $2865 \mathrm{~cm}^{-1}$ are assigned to $\mathrm{C}-\mathrm{H}$ stretching frequency. The peaks around 1712 $\mathrm{cm}^{-1}$ are assigned to the absorption frequency of the $-\mathrm{C}=\mathrm{O}$ and $-\mathrm{C}-\mathrm{N}$ groups. The peaks around $1105 \mathrm{~cm}^{-1}$ correspond to the groups of $\mathrm{Si}-\mathrm{O}-\mathrm{Si}$ and $\mathrm{C}-\mathrm{O}-\mathrm{C}$. All IR spectra indicate that the organic ligands were bonded onto silica gel.

The thermal stability of $\gamma$-GBSG and stationary phases has been investigated by TG analysis. The results show that the temperatures of weight loss for $\gamma$-GBSG and stationary phases are both more than $300^{\circ} \mathrm{C}$. It indicates that the new bonded phases possess high thermal and chemical stability. Moreover, the weight losses in $25-650^{\circ} \mathrm{C}$ were 7 and $13 \%$ for $\gamma$-GBSG and stationary phases, respectively, which was in line with the results of elemental analysis.
Table 2. Elemental analysis results of the bonded stationary phases.

\begin{tabular}{|l|c|c|c|c|c|}
\hline Bonded phase & $\mathrm{C} \%$ & $\mathrm{~N} \%$ & $\mathrm{~S} \%$ & $\mathrm{H} \%$ & $\begin{array}{c}\text { Bonded } \\
\text { amount } \\
\left(\mathrm{mmol} \mathrm{g}^{-1}\right)\end{array}$ \\
\hline$\gamma$-GBSG & 7.1 & 0 & 0 & 1.2 & 0.74 \\
\hline stationary phases $\mathbf{0 1}$ & 9.8 & 0.7 & 0.3 & 1.5 & 0.05 \\
\hline stationary phases $\mathbf{0 2}$ & 9.8 & 0.7 & 0.3 & 1.5 & 0.05 \\
\hline stationary phases $\mathbf{0 3}$ & 9.9 & 0.7 & 0.3 & 1.5 & 0.05 \\
\hline stationary phases $\mathbf{0 4}$ & 10.0 & 0.7 & 0.3 & 1.6 & 0.05 \\
\hline stationary phases $\mathbf{0 5}$ & 9.7 & 0.7 & 0.3 & 1.5 & 0.05 \\
\hline stationary phases $\mathbf{0 6}$ & 9.6 & 0.7 & 0.3 & 1.4 & 0.05 \\
\hline stationary phases $\mathbf{0 7}$ & 9.9 & 0.7 & 0.3 & 1.5 & 0.05 \\
\hline stationary phases $\mathbf{0 8}$ & 9.8 & 0.7 & 0.3 & 1.6 & 0.05 \\
\hline
\end{tabular}

The stability of the columns was evaluated over two months of being used under different chromatographic conditions. The relative standard deviations (RSDs) of retention time of analyte were less than $2 \%(n=6)$ during that time. The prepared columns showed high chemical stability when metanol mixtures and water (phosphate buffer, $\mathrm{pH}$ from 3.5 to 7.5 ) were used as mobile phases.

\subsection{Chromatographic Procedures}

Eight columns $(150 \mathrm{~mm} \times 4.6 \mathrm{~mm}$ i.d. $)$ were packed with modified calix[4] arene-silica gels according to a slurry packing procedure by using methanol as the displacing agent $(50 \mathrm{MPa}, 1 \mathrm{~h})$. The mobile phases used were methanolwater and methanol-phosphate buffers $(0.5 \%$, w/w, $\mathrm{pH} 4.5)$. Analytes were dissolved in the mobile phase at the concentration in range of $5-100 \mu \mathrm{g} / \mathrm{mL}$, and solution $(20 \mu \mathrm{L})$ was injected into the chromatographic column. The void time $\left(t_{0}\right)$ for the calculation of the retention factor was determined by injecting sodium nitrate $\left(0.05 \mathrm{M}, \mathrm{NaNO}_{3}\right)$ at $\mathrm{UV}$ detection $210 \mathrm{~nm}$, with $\mathrm{MeOH}-\mathrm{H}_{2} \mathrm{O}$ $(70 / 30, v / v)$ as mobile phase. All measurements were carried out at $25^{\circ} \mathrm{C}$ and repeated three times.

\section{RESULTS AND DISCUSSION}

In this section, the column factors are determined and followed by description of analytical results and analyte:bonded-phase interactions. Finally, the effect of organic modifier (methanol) is discussed.

\subsection{Column Factors}

The retention factors $\left(k^{\prime}\right)$ and the separation factors $\left(\alpha_{1,2}\right)$ of eight prepared columns were calculated and listed in table 3 . Separation factors were determined using the closest signal to the salbutamol's signal. This result indicates that new stationary phases can behave as excellent reversed-phase performance and the hydrophobic interaction is one of the factors playing a role in the separation of analyte.

Table 3. Column factors for separation of salbutamol on bonded-phases 01-08.

\begin{tabular}{|c|c|c|}
\hline $\begin{array}{c}\text { bonded } \\
\text { phase }\end{array}$ & $\begin{array}{c}\text { retention } \\
\text { factor }\end{array}$ & $\begin{array}{c}\text { separation } \\
\text { factor }\end{array}$ \\
\hline $\mathbf{0 1}$ & 2.2 & 1.7 \\
\hline $\mathbf{0 2}$ & 1.9 & 1.9 \\
\hline $\mathbf{0 3}$ & 3.1 & 1.7 \\
\hline $\mathbf{0 4}$ & 3.1 & 1.8 \\
\hline $\mathbf{0 5}$ & 2.1 & 1.7 \\
\hline $\mathbf{0 6}$ & 1.8 & 1.7 \\
\hline $\mathbf{0 7}$ & 2.9 & 1.7 \\
\hline $\mathbf{0 8}$ & 3.0 & 1.7 \\
\hline
\end{tabular}

\subsection{Analytical Results}

The graph of the peak area (y) against concentration $(\mathrm{x}, \mu \mathrm{g} / \mathrm{mL})$ proved linear in the range from 0.1 to $20.0 \mu \mathrm{g} / \mathrm{mL}$ and the regression coefficient $\mathrm{R}^{2}$ $=0.9996$. The limit of detection (LOD), was defined as the injected quantity 
giving $\mathrm{S} / \mathrm{N}$ of 3 (in terms of peak area), was found to be $0.01 \mu \mathrm{g} / \mathrm{mL}$. The limit of quantitation (LOQ), was defined as the injected quantity giving $\mathrm{S} / \mathrm{N}$ of 10 (in terms of peak area), was found to be $0.05 \mu \mathrm{g} / \mathrm{mL}$. Inter-day precision was assessed by injecting the standard solution of different concentration $(0.2,2.0$, $20 \mu \mathrm{g} / \mathrm{mL}$ ) and on each day for 5 days.

The results show that there were high inter-day precisions, the RSD\% of retention times was within 0.03 and the RSD\% of peak areas was within 2.5. Intra-day precisions were assessed by injecting the standard solution at the three concentrations five times during a day, and the intra-day RSD $\%$ of retention time was within 0.03 and the RSD\% of peak area was within 1.5 . The accuracy of the method was determined by recovery experiments. The analysis of salbutamol in the livestock meat showed high accuracy with a recovery of $95 \%$. The chromatograms of salbutamol in the livestock meat using stationary phases 01-04 are shown in figure 4, from which it is obvious that salbutamol was obtained better separation from the matrix in the livestock meat. The residues of salbutamol in the livestock meat were $0.10 \mu \mathrm{g} / \mathrm{g}$.

In figure 4, the upper chromatograms (st.) depict the standard solution containing salbutamol $(0.2 \mu \mathrm{g} / \mathrm{mL})$ and the other traces show the chromatograms of the following samples: pork (P), pork casing (PC), beef (B), beef casing $(\mathrm{BC})$, mutton $(\mathrm{M})$ and mutton casing $(\mathrm{M})$, respectively.

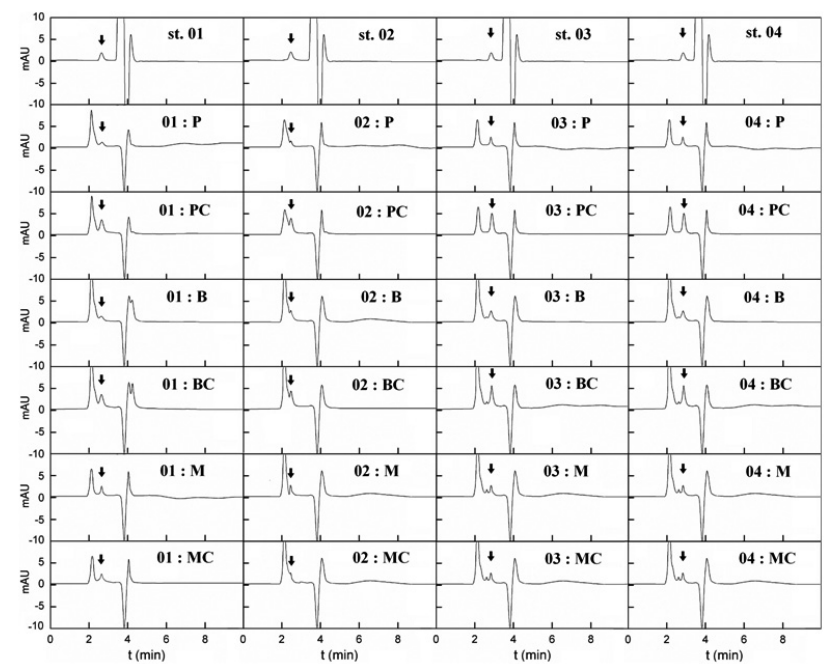

Figure 4. Chromatogram of salbutamol in six livestock meat (pork, pork casing, beef, beef casing, mutton, and mutton casing) using stationary phases 01-04.

\subsection{Column:Analyte Interactions}

The aromatic rings, $\mathbf{X}$ groups (were defined previously) and the cavity of the calix[4]arene play the additional roles on the separation mechanism for the salbutamol. These additional interactions are possibly inclusion complexation, $\pi-\pi$, hydrophobic, and hydrogen bonding interactions.

In all bonding phases 01-08, the hydrophobic interaction was mainly responsible for the retention behavior of salbutamol, and the columns exhibited good hydrophobic interaction properties except for columns 02 and 06 . At the same time, from the chemical structures and the chromatograms it was obvious that salbutamol can easily form hydrogen bond via it's $\mathrm{OH}$ and $\mathrm{NH}$ functional groups with the relevant groups on the calixarene-bonded phases. Moreover, the electronic-rich cavity of calixarene can attract the functional groups mentioned above on the salbutamol, which seems to be more for bonded phases 02 and $\mathbf{0 6}$.

\subsection{Effect of Organic Modifier}

Figure 5 illustrates the plot of logarithmic retention factor of salbutamol against the volume percentage of methanol in the mobile phase. As methanol content of the mobile phase increasing, the retention factors are decreasing. This result indicates that the new stationary phases can behave as an excellent reversed-phase performance and the hydrophobic interaction is one of the factors playing a role in the separation of salbutamol. However, it is obvious that the relationship between $\log k^{\prime}$ and the content of methanol is not linear. Moreover, by increasing the methanol contents to certain values, the relationship line of $\log k$ ' and methanol content tends to be flatten, which means that there exist other interactions in the separation process when the methanol content was in the low levels. Hence, it indicates that hydrophobic was not the only factor in the separation of the solute and the $\mathbf{X}$ functional groups may also be responsible for the retention behavior. According to figure 5, when the methanol content was in the low levels, all bonded phases show different $k$ values; while at the higher levels of methanol, they depict just two $k^{\prime}$ values. These results revealed that inclusion complexation, $\pi-\pi$ and hydrogen bonding interactions in bonded phases $\mathbf{0 4 , 0 8}$ are the most and followed by the order of $02,06<01,05<03,07<04,08$.

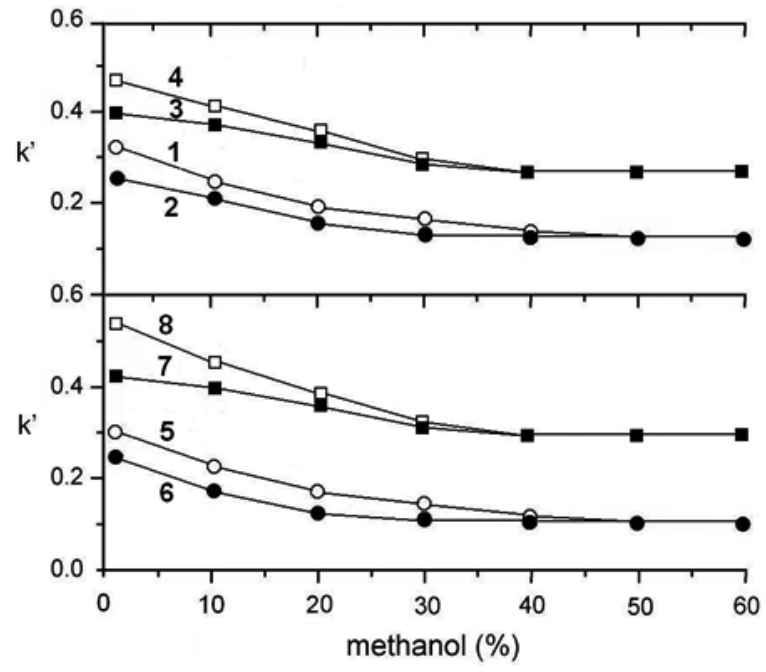

Figure 5. Effect of the methanol content of mobile phases on the logarithmic retention factor of salbutamol on bonded phases 01-08.

\section{CONCLUSIONS}

Eight new $p$-tert-butylcalix[4]arene columns containing sulfonyl carboxamide groups in partial-cone conformation were prepared and characterized by FTIR, elemental and thermal analysis. The chromatographic behaviors of new developed stationary phases were investigated towards salbutamol using six samples of livestock meat. By increasing the methanol content of the mobile phase, the retention factors were decreased and showed that various chromatographic retention mechanisms occur in the separation of the above analyte, such as $\pi-\pi$ interaction, hydrogen bonding interaction and inclusion complexation. The columns were successfully used for the analysis of salbutamol pork, pork casing, beef, beef casing, mutton, and mutton casing except for columns 02 and 06 .

\section{ACKNOWLEDGEMENTS}

This work was supported by Islamic Azad University (Shahreza branch) and Iran Nanotechnology Initiative Council.

\section{REFERENCES}

1. E. Shishani, S. C. Chai, S. Jamokha, G. Aznar, M. K. Hoffman, Anal. Chim. Acta 483, 137, (2003)

2. J. F. Martinez-Navarro, Lancet 336, 1311, (1990)

3. S. Maistro, E. Chiesa, R. Angeletti, G. Brambilla, Lancet 346, 180, (1995)

4. B. Mokhtari, K. Pourabdollah, N. Dalali, J. Incl. Phenom. Macrocycl. Chem. 69, 1, (2011)

5. B. Mokhtari, K. Pourabdollah, N. Dallali, J. Radioanal. Nucl. Chem. 287, 921, (2011)

6. B. Mokhtari, K. Pourabdollah, N. Dalali, Chromatographia 73, 829, (2011)

7. B. Mokhtari, K. Pourabdollah, Asian J. Chem. 23, 4717, (2011)

8. B. Mokhtari, K. Pourabdollah, J. Coord. Chem. 64, 3189, (2011)

9. B. Mokhtari, K. Pourabdollah, J. Incl. Phenom. Macrocycl. Chem. article in press, (2012) DOI:10.1007s10847-011-0062-z.

10. B. Mokhtari, K. Pourabdollah, J. Incl. Phenom. Macrocycl. Chem. article in press, (2012) DOI: 10.1007/s10847-011-0052-1

11. B. Mokhtari, K. Pourabdollah, J. Incl. Phenom. Macrocycl. Chem. article in press, (2012) DOI: 10.1007/s10847-011-0099-Z

12. B. Mokhtari, K. Pourabdollah, N. Dalali, J. Coord. Chem. 64, 743, (2011)

13. B. Mokhtari, K., Pourabdollah, J. Coord. Chem. 64, 3081, (2011) 
14. B. Mokhtari, K. Pourabdollah, B. Korean Chem. Soc. 32, 3855, (2011)

15. B. Mokhtari, K. Pourabdollah, B. Korean Chem. Soc. 32, 3979, (2011)

16. B. Mokhtari, K., Pourabdollah, J. Coord. Chem. 64, 4029, (2011)

17. B. Mokhtari, K., Pourabdollah, J. Coord. Chem. 64, 4079, (2011)

18. B. Mokhtari, K. Pourabdollah, Supramol. Chem. article in press, (2012) DOI: $10.1080 / 10610278.2011 .605452$

19. B. Mokhtari, K. Pourabdollah, J. Therm. Anal. Calorim. article in press, (2012) DOI: 10.1007/s10973-011-2014-7

20. B. Mokhtari, K. Pourabdollah, Electroanalysis. article in press, (2012) DOI: 10.1002/elan.201100584

21. B. Mokhtari, K. Pourabdollah, J. Electrochem. soc. article in press, (2012) DOI: $10.1149 / 2.048203$ jes

22. C. Ding, K. Qu, Y. Li, K. Hu, H. Liu, B. Ye, Y. Wu, S. Zhang, J. Chromatogr. A 1170, 73, (2007)

23. M. Sliwka-Kaszynska, G. Gorczyca, M. Slebioda, J. Chromatogr. A 1217 329, (2010)

24. C. Schneider, T. Jira, J. Chromatogr. A 1216, 6285, (2009)

25. M. Liu, L. S. Li, S. L. Da, Y. Q. Feng, Talanta 66, 479, (2005)

26. Y. K. Lee, Y. K. Ryu, J. W. Ryu, B. E. Kim, J. H. Park, Chromatographia 46, 507, (1997)

27. M. Pietraszkiewicz, O. Pietraszkiewicz, W. Zielenkiewicz, E. Uzig, P. Prus, Z. Brzózka, K. Woźniak, R. Bilewicz, T. Borowiak, M. Mączyñski, Chemistry, Computational Simulation 1, 547, (2000)

28. H. Hashem, T. Jira, Pharmazie 60, 186, (2005)

29. O. I. Kalchenko, S. O. Cherenok, A. V. Solovyov, V. I. Kalchenko, Chromatographia 70, 717, (2009)

30. H. Hashem, Chromatographia 71, 31, (2010)
31. H. Hashem, C. Tründelberg, T. Jira, Chromatographia 71, 91, (2010)

32. M. Barc, M. Sliwka-Kaszynska, J. Chromatogr. A 1216, 3954, (2009)

33. L. S. Li, M. Liu, S. L. Da, Y. Q. Feng, Talanta 62, 643, (2004)

34. K. H. Krawinkler, N. M. Maier, E. Sajovic, W. Lindner, J. Chromatogr. A 1053, 119, (2004)

35. T. Sokoließ, U. Menyes, U. Roth, T. Jira, J. Chromatogr. A 898, 35, (2000)

36. J. D. Glennon, E. Horne, K. Hall, D. Cocker, A. Kuhn, S. J. Harris, M. A. McKervey, J. Chromatogr. A 731, 47, (1996)

37. J. D. Glennon, E. Horne, K. O’Connor, G. Kearney, S. J. Harris, M. A. McKervey, Anal. Proc. 31, 33, (1994)

38. T. Sokoließ, U. Menyes, U. Roth, T. Jira, J. Chromatogr. A 948, 309, (2002)

39. S. Gebauer, S. Friebe, G. Gubitz, G. J. Krauss, J. Chromatogr. Sci. 36, 383, (1998)

40. S. Gebauer, S. Friebe, G. Scherer, G. Gubitz, G. J. Krauss, J. Chromatogr. Sci. 36, 388, (1998)

41. X.Z. Xiao, Y.Q. Feng, S.L. Da, Y. Zhang. Chromatographia 49, 643, (1999)

42. W. Xu, J. S. Li, Y. Q. Feng, S. L. Da, Y. Y. Chen, X. Z. Xiao, Chromatographia 48, 245, (1998)

43. Q. Y. Huai, B. Zhao, Y. M. Zuo, Chromatographia 59, 637, (2004)

44. B. Mokhtari, K. Pourabdollah, Supramol, Chem. Article in press, (2012) Doi: 10.1080/10610278. 2012. 655278.

45. B. Mokhtari, K. Pourabdollah, Desalimation. article in press, (2012) DOI: 10.1016/J. desal. 2012.02.004.

46. B. Mokhtari, K. Pourabdollah, Drug Chem. Toxical. Article in press, (2012) DOI: 10.3109/01480545. 2011. 653490 